\title{
Diseases and The Possible Effects that The New Media Brought into The Digitalizing World
}

\author{
Övür A. ${ }^{1}$ \\ ${ }^{1}$ Ayten ÖVÜR, Istanbul Aydin University, (Turkey) \\ e-mail: aytenovur@aydin.edu.tr
}

\begin{abstract}
In this day and age where it is impossible to run away or stay away from technology and digitalization, every invention and progress bring along possible danger. Possible issues that the people who are always on their phone or the people who work sitting on computer all day long and the connection between diseases of our age and those technologies has reached unignorable sizes. The objective in this study which is prepared with a critical approach is to research those possible problems and evaluate on magnitudes they can reach in the future.
\end{abstract}

Keywords: New media, digitalization, disease

\section{Introduction}

Nowadays the number of people who do not use new media technologies decreases day by day. From peasant to townee, young to old, rich to poor almost everyone can reach and express themselves in the new media, which seems to be the new" modern fantasia" field. Just like the studies and researches communication scientists have done about the "effects of television" for years," new media" topic is a center of attraction for the researchers of our day.

New media as a growing and developing topic occupies most of our lives. Unlike the old generation, which spended most of their time watching television to get away from reality and provide virtual relief, new generation prefers new media platforms. New generation which spends most of their time on the computer, playing games, wandering on social media, watching movies/tv series, following current events also steals the time spared for other works to reach the same platforms on their phones. They can not give up their phones while walking, travelling, driving, crossing the road, hanging with their friends, spending time with their families and doing many other things. The families which used to sit their child in front of the television to look after them now uses phones and tablets as a way out. Some foundations thinking internet addiction will increase in next generations think childrens' relationship with the technology should be limited, therefore they make some public service announcements like the ads The Green Crescent makes.

It is reported that new media's possible harmful effects should be avoided without ignoring realities of the time or falling behind developments. In this study which the digital addiction and its' possible effects will be questioned, the concepts "digitalization" and "new media" will be clarified and then possibles diseases and effects will be tried to be revealed.

\section{Digitalization}

In the Turkish Language Institution Dictionary, "digital" is explained as "numerical" and is defined as the display of the data electronically on a screen. With this definition "digitalization" 
can be expressed as "digitization" and "digital conversion" can be expressed as "numerical conversion". However, these definitions describe digitalization in a narrow sense. Because digitization is a starting point for digitalization, it has been understood that, when evaluated together with the transformation, there is a need for a definition describing a process in which the digitization expression is not sufficient and that any digitized data can be used, processed and interpreted. (Karagöz, 2016: 72).

"Digital" is a technical term used to define media and systems based on electronic calculating. That is to say, any kind of data expressed as "analogue" is represented by binary codes (Alioğlu, 2011: 119) The datas transfrred from the analogue system to the computer enviroment is expressed as "digitally". The digitality characteristic which is revealed by transferring analogue data to computer based systems also brings easy and quick access to data (Yengin, 2012: 126). Digitalization describes to the process of converting analogue materials such as drawings, photographs, videos, audios into digital forms. Digital systems render all the information or the input, storable, workable, sharable widely. It can be seen that instead of the digital concept corresponding to the conversion of data into numeric codes, the concept of quantification is used in some Turkish researches. The reason for the perception of digital digitization is related to the representation of the data with " 0 " and " 1 " when coding. (Güney, 2014: 14-15).

The concept "digital" which expresses a concept called binary system describes two logical possible situations that electronic circuits can take, which is the basis of computer systems. It is expressed by close as the electricity is not passing through and open as the electricity is passing through. In the notation with symbols, (0) is used as open and (1) used as closed, for example "01100001" as the character "a" in the computer operating system. The explanation of this symbol sequence is that; when the electricity flows through the second, third and eighth circuits of eight electric circuits, we get the character "a". For the character "b", the symbol sequence "01100010" is used. That is, when the electrity passes through the second, third and seventh circuits of eight electric circuits, we get the character "b". There are no other numeric meanings of $0 \mathrm{~s}$ and $1 \mathrm{~s}$ but to report a situation. There are some logical meanings though. Using yes/no, on/off instead of them does not make any difference. Therefore, according to Cem Sefa Sütçü, the provision of the concept "digital" can not be numerical. The most important function of digital is to allow objects to be virtualized, duplicated and transmitted over electronic networks (Sütçü, 2012: 84).

The concept "digital" which was derived from the latin concept "digitus" was first used to mean "related to fingers and using numerical digits". Digit (binary number system) has been moved to a new concept substantiality with the computer technologies, which can be explained as the principle of operation with logical operations that are mainly developed when an electric circuit is turned on or off according to the transition of the electrical signals. Digital, is used nowadays as the the enviroments provided by computer technologies and all the productions made by these enviroments. In this context, some researchers do not prefer to use the concept "numerical" because it is also used as the opposite of the word "linguistic" in our country. On the other hand, some researchers do not prefer to use the concept "numerical" because it can not fully meet the content of the concept "digital" (Güney, 2014: 14-15).

Today, when almost everything can be digitized and expressed in numbers, the definiton of data has changed. The digitalizing world reveals the concept of Big Data, which refers to collecting, storing, searching, visualizing, analyzing data stacks using existing systems and Technologies (Öztürk, 2017: 242). In the digital era we are in, where there is unlimited number of information and it is difficult to distinguish between real and fiction readers' consumption of news has also changed. In this context, the rise of digital media is continuing every year and it is expected that this increase will continue in the following years. According to the datas announced in april 2015, the revenue of digital publications leaving print publications behind also once again shows the importance of change (Yalçın, 2017: 175). Especially in internet advertising, the share of social media advertising increases day by day. 
While social media quickly captures every moment of our lives at the same time it also changes the processes of the traditional media. It does not allow any media channel that has not managed to integrate with itself to remain in our lives for a long time (Kahraman, 2014: 21). Nowadays, the major media companies have also started to use digital, but the debate over whether digital media is threatening traditional media is still ongoing. Examples of this has happened. The Inpedendent newspaper has closed down to only digital (Öztürk, 2017: 244). In Turkey, the Radikal newspaper has left the traditional method and started to make only digital publication.

Time will show the dimensions of the contest, the interaction and the transitions between the new media and the old media but over the past thirty years, the rise and unification of network media and communication technologies have helped creating new forms and styles of communication and redefining people's interaction with the media (Lievrouw, 2016: 11). Full participation in today's digital culture requires not only consumption of messages but also their formation and sharing. In order to fulfill the requirements of digital citizenship, individuals now have to acquire multimedia communication skills and know how to use them (Salı, 2012: 294). "I do not use this" is no longer an excuse. Citizens who want to do their jobs quickly are forced to use digital communication tools, even at a minimum level. Even when you go to a hospital you need to make an appointment on the internet. Same transactions are required while renewing passport, ID etc. It is no longer possible to not have an interaction with digitalization in an age where it is required to be in touch with digital technologies to wait in the bank, the notary or any other institution.

\section{New Media}

Unlike the traditional media (books, newspapers, television and radio) the concept "new media" used to describe digital media, especially interactive media, internet networks and social media. The concept "new media" covers information and communication technologies and related social contexts, devices that enchance communication skills, communication activities and practices developed using these devices and social arrangements or organizations that are shaped around practices with these devices (Binark, 2014: 15).

New media allows fast communication between different communities of people with completely different experiences in different regions of the world through community networks, messaging enviroments, blogs and other user-specific content forums. In other words, it makes it possible for millions of people to communicate and share all kinds of transmissions on a plane of magnitude and opennes that could not be imagined before or during the periods when internet technology was not widespread (Erdoğan, 2014: 80).

The word "media", which is the plural of the Latin-based medium, can be translated to Turkish as enviroments and is used to describe the enviroments in which the message is transmitted. The concept "new media" is usually identified as the digitalization of the existing media into digital data, provision of interactive communication, changing production, distribution and communication forms through new technologies (computer, internet, mobile technology) (Güney, 2014: 16). These new enviroments and technologies ensure that the message can be transmitted in the fastest way bidirectionally.

The concept "new media" is also described as production, distribution and communication forms that are developed through computers that direct existing media to interactive, numeric data conversion. Therefore, with the emergence of the new media, the digitalization of all old forms of media, the transformation of common values $(0 / 1)$ is bound to happen. This partnership ensures that the new media can reach a much wider audience (Alioğlu'dan akt. Kıpçak, 2016: 13).

Leah A. Lievrouw and Sonia Livingstone describe the new media as information and communication technologies and their social contexts. The three components that make up this social context are as follows: 1) material structures and tools that enable people to expand their meaning-sharing and communication capabilities; 2) communication actions and practices that 
people attempt to use and improve on these tools; 3) broader social arrangements and organizational forms that people have created and built around these structures and practices (Lievrouw, 2016: 17). These material structures and tools that expand and enable the communication skills are changing and developing so rapidly unlike the old media; that the people are constantly updating their communication practices and practices to use these tools.

The cyber space created by new media environments also reveals a unique culture, new types of relationships specific to individuals and communities. Today, computers, computer networks, computer mediated communication, internet, web 2.0, online journalism, online chat, chat rooms, wiki, e-commerce, e-signature, social media, digital media, digital game, digital culture, digital imaging, avatar, cyber space, virtual space, virtual reality, enhanced reality and the social, cultural and economic phenomenons that these concepts describe, have become a natural part of our daily conversations. The concept that covers and unifies all these concepts is the new media (Akt. Binark ve Bayraktutan, 2013: 17-18). With each passing day, innovations are added to these concepts and the possibilities of new media are increasing.

According to another definition, the new media is a two-way, 'hybrid' medi-tage, one of them is specific to computers (information-processing) and the other is specific to communication tools (communication-telecommunication and publishing). Therefore, the concept of new media is used to characterize the means of communication more peculiar to the these days (in the sense of a transformation and continuous renewal process). Lev Manovich tells us that the media has turned into new media as graphics, moving images, sounds, forms, places and texts become computer data (Akt. Akca, 2014: 28). As you can see, there are many definitions about new media. Although the issue of what the new media is and what is not and is considered an open and ongoing debate, some definitions focus entirely on computer technologies while others focus on cultural forms and texts such as art, film, trade, it is concentrated. Finding out what the new media is and what it is not can help in understanding the concept. Unlike the popular opinion, new media do not mean internet. Today, the technological tools of communication are with us anytime and anywhere, and the convenience in accessing the internet and social networking and it leads to the mention of the new media concept with the internet. However, the basic terms used to explain the concept of new media include; computerization, digitization and digitalization (Kıpçak, 2016: 13).

It is also possible to better understand what the new media is by looking at the differences between New Media and traditional media. In the new media, the following features appear to be at the forefront: digitality, interactivity, hypertextility and modularity. Digitality is the conversion of new media text into numeric codes in the form of $0-1$. This feature feeds storage capacity and reproducibility. Interaction can occur between the user and the virtual personality or between the virtual personality and the user. In the case of multiple users' virtual diving, the environment becomes a common world where the avatars of users can interact with one another. In here, it is in the position to plunge, embed, embed into the story in the text, perform the ideal literate role (Binark ve Bayraktutan: 2013: 19). The interactivity feature, which is the ability to interfere with the content of the user's data, makes the user who is in a passive role in the communication process an active role. The hypertext feature is; expressing the connection between texts. The texts are linked within themselves. For example, being able to quickly access other news contents linked to that news while reading a news item represents the hypertext feature. Modularity is the ability to make changes to any one component while using different components under one roof. It is the possibility for different components to come together to form a single object in different ways. In the modular structure, a single object can be produced from a combination of objects in the form of parts, while mixed parts can be separated from each other. New media in this context; based on the digital coding system, is a communication area where high-speed interaction, which has hypertext and modularity properties, is happened in which individuals are active (Yengin, 2012: 127-128). These four characteristics appear to be common features used in new media definitions. Because of these features, the new media is shaking the traditional media's throne strongly.

The Web provides users with more content and navigation tools than traditional media usually provides. Massey and Levy indicate that the web also meets the need for "interpersonal 
interaction" because individuals can communicate with each other through tools such as chat rooms and bulletin boards (McMillan ve Hwang, 2016: 376). In addition, the information provided by the traditional media is politically informed by the mainstream and therefore does not contain dissenting and different opinions. However, unlike sovereign media organizations, the Internet's news networks overcome the power to create independent agendas for people or groups, to argue outside the mainstream, and to easily express oppositional views. At the forefront of the possibilities offered by internet technologies is that everyone on the internet is given the chance of low cost broadcasting. Traditional mass media can only exist on the basis of capital, which creates these three basic problems: (a) Depending on the agenda-capital relations-it is easily handled by manipulation, (b) communication is one way, it is almost impossible for citizens to become involved in the communication processes, (c) local information and debate can easily be fed in order to reach wider populace (Tunçel, 2014: 68).

In their studies of social media, Gürel and Tigli describe the former media consumer as passive, audience, stationary, predictable, constant, isolated and abstract, silent and invisible, compatible, obedient and open to manipulation (Akt. Yengin, 2015: 389). With new media, unilateral message transmission has evolved into an interactive communication model where feedback can be made People are more active now, They are not just followers but also they make people watched them. New media has changed the relationship between the sender of the message and the recipient of the message. New technologies, as a result of the digitization of old media formats, enable the media to come to a programmable position and make interactive communication possible. This leads to "digital cultural" formations in the virtual processes in which they communicate, without standing side by side, without eye contact with the eye, without needing a physical presence. The information, images and sounds are now rendered into digital data and are rendered in a simulated state that seems to have come true, but in an unrealistic position (Güney, 2014: 3). Thus, the universe of Baudrillard's simulation theorem, that is, the universe where the truth is destroyed and the place is simulated becomes the reality of all of us.

Individuals can now communicate only with their fingers using their fingertips. Through the tools with the touch interface feature, the "Network society" phenomenon described by Manuel Castells takes place and the internet that forms the basis of this forms the new media. It is the qualities of the new title which is determinant for the media defined as the communication environment in the communication field. Especially in environments represented by digital codes, individuals are digitized. What is important for digitization is to create interfaces that are not complicated and can do a lot of processing with little information. Especially a touchsensitive interface system has been developed so that individuals can carry out daily operations easily and without wasting time (Yengin, 2014: 7). Digitalized individuals tend to prefer environments that are similar in their real life and in their relationships and tend to be simpler, less complicated, pill information, easily distracted when they get bored, and they tend to struggle with many things at the same time with difficulties in providing long-term interest.

On the other hand, according to Christian Fuchs, cyberspace does not mean a completely new world, although it changes many things in society. The conflicts over private ownership, authority and symbols seen in modern society and old problems have taken a new form. Cyberspace has created new problems such as the structure of information, private and public ownership and their democracy effects, the threat of surveillance of the privacy of private life, the virtualization of relations. The emergence of social groups has left a new milieu in which face-to-face interactions and interactions are a necessity, where the development of information communication technologies and the effect they create and the social interaction can be virtually completed, a physical proximity to communicate and socialize becomes a necessity (Çakır, 2014: 90, 221). However, these new environments have opened the way for alienation and took the level of one's alienation against their lives, theirselves and to their relatives to a higher level.

In spite of such negative influences and various criticisms that the new media brings, it is consolidating its position as a communication form of our present and future. This puts today's communication scientists into an obligation to correctly analyze the new media and to show the benefits and consequences correctly.

DOI NO: 10.7456/ctc_2017_02 


\section{Digital Addiction}

Digitalization causes a lot of changes in our lives, from our relationships with the environment to our perception of events. The fact that the young population begins to be characterized by concepts such as "born digital", "digital native", "digital generation", "touch society", "network society" can be regarded as a reporter of these changes (Güney, 2014: 4).

The most widespread use of the internet is the generation called digital natives and born into this technology (Akca, 2014: 8). Digital natives consist of 21st Century youth who are familiar with digital media tools, center these tools on their lives and carry out all their day-today business with this technology. Marc Prensky says that life of digital natives are surrounded by computers, video games, digital music players, video cameras, mobile phones and all other tools and toys of the digital age. Also, Prensky mentions that digital natives use the digital language of computers, internet and video games as their mother tongue. Digital natives socialize in different ways than their parents. Digital natives spend more than 10.000 hours playing video games, 20,000 hours watching television, over 10,000 hours speaking on the phone, 200,000 hours sending and receiving e-mails in the process of college graduation. In total, they read books for up to 5,000 hours (Kürkçü, 2016: 191). Digital inhabitants, who are always connected to the Internet, have many friends in the real world and in the virtual world. Friendship associations are also different from their parents in relation to information, and they think that information is something they can easily shape. They are endlessly confident that they can get all the information they need to maintain their lives from the virtual environment they are connected to. Digital natives within the digital ecosystem contribute to the digital world by connecting to the internet from different parts of the world, sharing their knowledge, communicating, organizing and seeking their rights (Karaduman, 2014: 107).

The most disadvantaged group in the use of Internet technologies is the group of elderly people, also called X generation (Akca, 2014: 9). Digital immigrants born in the early 1980s are people who are not familiar with virtual reality and digital media tools, such as digital natives, and are trying to adapt to this digital culture. Digital immigrants are those who are trying to learn digital language but are using this digital language accentuously, not being able to get rid of their past habits (Kürkçü, 2016: 190-191).

Digital foreigners are those who are not interested in technology, regardless of age, who do not deal with digital technology at all, who do not want to take advantage of the blessings they bring with the thought that harmful effects will be much more than its benefits. These individuals who see smartphones, the internet and technology unnecessary are not adopting to today's city life and the postmodern era by opting for natural life and nature interiors. Digital disabled are those who want to use digital technology but do not succeed in it and are constantly in need of digital natives' support. The slightest change or glitch in the system becomes a big problem for digital disableds and they need the help of digital natives, unable to run the system again. For digital natives, telling technological innovations and working systems to digital disableds is both a long and a rather tedious and difficult task. Because they can not understand how digital disableds have failed such simple tasks for themselves, and they have difficulty in expressing them in a plain and simple way. However, dealing with digital technologies which is part of their lives as natural as eating and drinking water for digital natives, over time, make them addicted to these technologies and unable to do anything without them.

Addiction is also referred to as reward failure syndrome and just like the item internet is making an reward failure. The basic element of the pleasure sentiment associated with the reward penalty system in the mind is the things that increase dopamine and dopamine. One of the risks of the Internet generation is very closely related to the increase in dopamine secretion in technology's headquarters and its dependency. According to Nevzat Tarhan, if the person falls into a depression in an environment where the internet is not available and if it interferes with daily activities, it means addiction has begun (Tarhan, 2017). 
"For many years, we thought that addicted people were doing it because they liked that movement or behavior, but it was understood that it was about dopamine," says Gerald Moore, in his research on addiction and dopamine relationship, explains why the brain wants more in addiction. According to Moore, whenever we are experiencing pleasure and excitement, the brain secretes dopamine at high levels. Dopamine allows the continuation of that movement. When a behavior that gives pleasure to us is made repeatedly, the level of dopamine begins to rise, and that action must be continued in order to maintain or enhance that level. The person hates what he actually does, but the dopamine secretion is so high that it repeats that behavior (Moore, 2017).

As consumers of media products, people are also dependent on media content in order to get pleasure, emotional well-being and avoiding everyday tensions, running away from world realities, getting out of distress, forgetting bad experiences, improving personal relationships, making friends, getting rid of loneliness, influencing others, getting within their sight, appreciation-esteem, to win aesthetic and literary skills; else to see that their beliefs are confirmed and to locate themselves and others in order (Demir, 2013: 112).

Internet addicts spend time on sites such as movie-music sites, game sites, chat sites, social media, pornographic sites, community sites. For non-Internet addicted users, they spend more time on information, shopping, and educational sites than Internet users. In problematic internet usage, it is stated that the Internet is one of the important factors for social interaction and enjoyment and use. In addition to the time spent on the Internet, in other words 'internet usage purpose' is shown as a strong variable that predicts dependence (especially use of internet for interaction purposes). In one opinion, the reason that some individuals use so much internet is that it offers communication experiences that they like, and this overuse also causes addictive behaviors (Tiryaki, 2015: 176).

Addiction is defined as a chronic brain disease that causes structural and functional disorders in the brain. Articles and virtual mediators change the structure and functioning of the brain. Researches reveal that gambling, shopping, sports, cybersex, technology and internet are addictive in the brain besides drinks and cigarettes. Addiction is directly related to the award penalty system in the brain. The person who has internet / computer addiction gradually makes it the center of his life. Social relationships evolve or end depending on other people's attitudes towards the activity on the internet and the computer and their ability to participate. There is a consciousness change that is caused by the use of computers and internet, internal chemical stimuli related to the activity on the internet or on the computer, such as in sexual stimulation, gambling and games. Moreover, the internet permits the exchange of identity and this creates a unique enthusiasm. Typical symptoms of addiction are computer busyness and intensive use of images. When you are offline, you can think of the internet constantly, you can not control the usage time, you lie about the usage time, and you use internet to escape problems. There is a pathological level for those who see the risk of risking important relationships and affairs because of the Internet. According to Tarhan, age, education and economic situation are also decisive factors in addiction. Two thirds of Internet users are men and men are more likely to be addicted than women. Another important factor that increases the risk of addiction is economic factors. (Tarhan, 2016).

Onur Noyan, who said that loneliness and introversion are some of the factors that increase the addiction, stated that he preferred to use the "use disorder" instead of internet addiction, emphasizing that his / her perception of his / her time was deteriorated due to the use disorder, emphasizes that sleep quality falls, especially with the use of smartphones at night. In a study conducted, Noyan stated that $40 \%$ of the individuals were found to wake up and check their e-mails at night, revealing the addiction spiral as follows: "Personality traits such as loneliness and introversion are a facet of digital addiction in social media. The most basic factor in the addiction process is getting pleasure, entering that site gives you more pleasure and makes you enter again and again. Friends are the biggest factor, we wonder what they are doing. These features make people more inclined to social media. The Internet is an active entertainment. You are in control of the process. For example, when you are successful in the process you are in control, you share and get likes and comments in social media. That is the 
reward. If you have a lot of options, you increase the prize. For this reason we are constantly sharing something in social media. How much fav / retweet that much pleasure, how much appreciation is that much pleasure and addiction loop" (Noyan, 2017).

It is called a delusion of illusion in which the fulfillment and the pleasure play a central role in the motivation and we do not take into account the relation to reality just as it does not attach importance to the evidence in the same way. According to Freud, the typical characteristic of illusions is that they originate from human desires. In this aspect they approach psychiatric illusions. But these are different from those that are much more complex. It can be said that the hypochondria are contradictory to the reality. But is not necessary that illusions are wrong, that is, they can not be realized or contradicted with reality. For example, a middle class girl could feed the illusion that a prince would come and marry her. This is possible; there have been several such incidents (Freud, 2007: 209).

However, by breaking completely from the reality and constantly bringing various illusions into the focal point of our life, attaching them brings psychological problems together, the individuals are dragging into escape fantasy areas and this leads to addiction after a while. Everything on the internet is like as if real. As if we have hundreds of friends, and as if we feel like we are meeting and enjoying them every day, as if we are that personality we created in social media, as if we are very happy, as if we are very sensitive, as if we are very beautiful, we live these illusions and we want to make our followers to believe these illusions too. But in real life usally the reality is not like this. In point of fact, we spent time alone at the computer for hours, not seeing true happiness to look like happy, forgotten to live to look like we were living, and could not experience the moment because of concentrating sharing the beauty of the scenery without drawing the beauty of the scenery to the inside. We have devalued the truth, we couldn't give its value, and we have become worshiped for the simulation.

According to the German philosopher Hans Vaihinger, who developed the "as if" philosophy, values and ideals, although irrational, are accepted and used even if they are found to be contrary to reason and logic, if they help the functions that serve life. When people arrive at the scene with phenomena, they accept or have to accept such fictitious or imperative realities that they can and can not do, "as if" they were real facts because these are things that have been found beneficial in biological and psychological terms. In other words, they are practical places that do not have any basis in fact but assign human behavior to a significant extent. When people face a lot of situations and experiences, they develop systems that will organize these experiences and then assume that these systems are real. According to Vaihinger, people are more affected by what they are expecting than they are living. Alfred Adler, here is in the view that fictional systems and expectations, role anticipations, are extremely influential on our social life and our personality. Adler says that all human behaviors, thoughts and feelings are shaped by this "as if". (Akt. Yörükan: 3). We are increasingly committed to virtual personalities and situations we have created in virtual worlds, such as imaginary situations we created on this philosophical basis and our commitment to ideals. This commitment and the working systems imposed by the age has opened the path of digital dependence together. Surveys and statistics show that internet usage and addiction are increasing day by day.

According to the Statistical Brain Research Institute's 2013 data, 54\% of the world's population is using any social media tool, and $98 \%$ of the $18-24$ year olds are a member of at least one of social media tools. 240 million of the 1.4 billion Facebook users make their access through smartphones. When one looks at the average time spent on social media tools in a month, with a 10.2 hour average Turkey ranks fourth after Israel, Argentina and Russia in the world (Altınbaş, 2014: 45). According to the Internet and Social Media User Statistics prepared by We are Social in 2014, internet users in Turkey spend an average of 4 hours and 37 minutes on the internet, 2 hours and 51 minutes on the mobile internet and 2 hours and 56 minutes on the social media. Users spend about 2 hours and 17 minutes per day on television (Yetişkin, 2016: 26). 
The data published by the Turkish Statistical Institute (TurkStat) annually shows that the use of the Internet has increased in Turkey every year. According to the "Household Information Technologies Usage Survey" released by TurkStat in 2017, the rate of individuals using the Internet in Turkey is $66.8 \%$. This figure is $61.2 \%$ in $2016,55.9 \%$ in 2015 and $53.8 \%$ in 2014. The rates of computer and internet usage are $56.6 \%$ and $66.8 \%$ in the $16-74$ age group in 2017 , respectively. These rates were $65.7 \%$ and $75.1 \%$ for males and $47.7 \%$ and $58.7 \%$ for females, respectively. The proportion of the dwellings with Internet access in Turkey reached $80.7 \%$ in April of 2017 . This rate is $76.3 \%$ in the same month of 2016 . That is, eight of the approximately ten dynasties now have internet access (TÜIK, 2017) According to the data of the year 2016, $59 \%$ of the households who do not have internet access from the house say they do not need internet usage as the reason for not connecting and $29.4 \%$ of them use internet, work, school, internet cafe and other places. While $96.9 \%$ of the households have mobile phones or smartphones, the rate of land phones is $25.6 \%$. Social media is the first place when it comes to internet usage. When Internet usage is taken into consideration, $82.4 \%$ of individuals who use the Internet in the first three months of 2016 have a social networking profile, send a message, sharing the content, watching videos from sharing sites with $74.5 \%$, reading online news, newspapers or magazines with $69.5 \%$, searching for health related information with $65.9 \%$, searching for goods and services with $65.5 \%$ Followed by listening to music over the Internet (web radio) with $63.7 \%$. Shopping over the Internet is also increasing day by day. The rate of individuals who use the Internet to order or purchase goods or services for personal use over the Internet has increased by 1 percentage point to $34.1 \%$ in 2016 compared to 2015 . The number of regular internet users has also increased. The proportion of Internet users who have used the Internet almost every day or at least once a week among individuals using the Internet in the last 3 months has been $94.9 \%$ in the first three months of 2016 (TÜIKK, 2016).

According to Mikolaj Jan Piskorski's study of cross-cultural differences in the use of social media, Asian users are using more social networks than westerners. In this, it is possible to see the effects of the economic factors mentioned by Tarhan. Brazil, Russia, India and China seem to join a much wider variety of social networks, despite the very limited technological possibilities. For example, users in China and India have twice as many video shares as Americans, and daily and instant information sharing (Twitter) is three times more (Gün, 2013: 98). When it comes to children's Internet usage and prevalence, it is seen that 85 percent of the children aged 9-16 are using internet to do their school work, 83 percent to play games, 76 percent to watch video clips, and 62 percent to instant messaging (Livingston, Haddon, Görzig ve Olafsson'dan akt. Çakır, 2014: 133). However, when compared with adults, the use of uncontrolled internet can have much more dangerous consequences because of the weakness and vulnerability of children during personality formation. Recently, news that children have been exposed to various threats and brainwashes through a game played on the internet and experienced deaths have been found on the agenda. Admitting vulnerabilities to addiction development and the information they receive from the internet without questioning makes them a clear target. This leads various institutions and organizations to take measures related to children's internet use.

\section{Digital diseases and possible effects}

The increasing use of the Internet, the time spent on smart mobile devices and computers also brings with it some physiological and psychological problems. In addition to various psychological disorders such as Internet addiction, Netlessphobia and Nomophobia, physical discomforts such as Carpal Tunnel Syndrome, waist and neck stiffness are also seen to increase. It is also argued that wireless internet raises the risk of cancer and that people are facing the risk of obesity resulting from irregular feeding or frequent snacking while working with computers.

The results of the research conducted in recent years show that children's access to online environment, privacy, security, health, ethics, communication, etc., they are experiencing problems in dimensions. Widespread access to information and information resources confronts children with both advantages and disadvantages of the digital age. David Miles says that children's deprivations of digital culture and media culture make them vulnerable to the misuse 
of the technology concerned and that children are taught to make good decisions to stay safe at home and at school and they also need to help them make good decisions online too (Akt. Karaduman, 2014: 110,114).

While the increasing amount of time spent on the computer is the question and debate about the "real" nature of social relations, the other dimension is the revitalization and maintenance of friendships that have not been communicated for a long time or are lost through technological possibilities. Another aspect of the situation is related to the exhausting and tiring effects of communication intensity. This quality can also cause the rapidly developing relationships to end up at the same speed in a short period of time. Another effect is shaped around private life and personal information. These technological environments that enable the development of social relations can also cause personal information to be damaged. Except for the fact that people open their own private information to other people, accessing their info without their permission damages personal privacy. It is especially difficult for children to develop their own personality, to keep their values under negative influences as well as positive effects in the shaping process, or to be confused by confounding "good" and conflicting personalities. In the process of membership to social networks, it is felt that children have to join social networks such as facebook, instagram with the non-concrete print of social environment or popular culture. When you are not a member, there is the possibility of being "out" or excluded somewhat (Dedeoğlu, 2016: 25).

The relevance of the new media generation to technology is spreading across a broad spectrum between being a good user and technology surrender. This new generation is a generation that adheres to enigmatic writing and is turned into language codes. In the age of new media, language has left its place to the title language and culture. The new language is a symbolic language composed of short codes and abbreviations. The new style of public speech constantly renews itself and makes it a dominant language. The best example of this is Twitter, which has a 140 character limit (Arar, 2014: 130-131).

The Internet, which includes radio, newspapers and television, that is, traditional media, adds a different language to people's lives as a result. This new language, which emerges from the internet, integrates all the constructs, unlike newspapers, radio and television, which can both listen and read and produce content (Gürer, 2015: 44). In the age of the Internet, ready information has become sacred and important. This is especially true for journalists and news consumers. With thousands of newspapers and other online news sources, we are at an age when it is easier to access information than at any time in history. But at the same time, information overload has become a fact of life (Pavlik, 2013: 271).

The perceptions altered by digitalization cause the virtual to replace real in the world as the boundary between real and virtual space gradually disappears, and many situations that reveal it are encountered. In the virtual environment where the language boundaries are exceeded by visuals, people communicate with different people in many places of the world but ignor their neighbors or their problems and neglect their relatives while struggling with the problems of the global scale are examples. Individuals who think that they are liberated by being attracted to the virtual charm by their perception that they have unlimited rights, are in fact losing their self by chosing their virtual identities. Behaviors, such as the feeling of being free when playing around on "virtual fences", are the paradoxes of digitalization (Güney, 2014: 5). Another paradox is the reflection of political thoughts. By participating in an act on the street and being exposed to a punk bullet or gas bomb, it can meet the need for political participation in a safe and secure manner in the face of political events. However, with the new measures taken by the governments, this virtual relaxation can be prevented. They have begun to develop a strong self-consciousness in the sharing and enjoyment of individuals, thinking that the information in digital media has never completely disappeared.

It is not only communication-mediated spaces that are virtualized on the Internet, but also the identities of those who do not come face to face, but who form the public opinion by entering a temporary dialogue for specific purposes. In the field of artificial reality, physical appearance has become completely reorganizable. The physical appearance is free to play as 
we wish. In any case we can choose to be long or short, we may want to be thin or fat (Tunçel, 2014: 70). But in real life this is not the case at all. Changing the facts is not as easy as in the virtual world. We are whatever and whoever we are. We use the gates of the virtual world for escaping these immutable and annoying facts. In our new contemporary fantasy space, we build an identity like we want, hide our parts we do not want, see only the people we want, talk and build a sheltered world. However, when this psychological relief can not be found in real life this time another problem arises. It is not that easy to get rid of the facts that we are uncomfortable, like the environment, the people or our features. It is then necessary to struggle hard to change the facts or to reach out unreal dimensions to feel a virtual relief. This delirious state of daydreams goes on and on in the form of an on/off as in 0 and 1.

When we look at our semi-real, semi-virtual lives in our Timeline, the feeling of reality that we see in our screen as the film strip, attracts us. It is even more difficult to get rid of it if we start to disappear in it like a vortex. The number of moments we have stolen from our real life for our virtual life is increasing day by day. The feeling of emptiness that emerges after we leave it, the indifference to the real life and the fact that the problems have not disappeared, increase the desire to return to our simulation as soon as possible.

Virtual media is not only about creating virtual identities, but also introducing the concept of virtual community into the literature. According to Rhingold, "the virtual community is an area where a sufficient number of people have made public debate on the internet, long enough, with sufficient human emotion, and created a network of personal relationships. Unlike compulsory communities formed in a physical space, virtual communities reflect the voluntary bonds of individuals with their chosen communities (Tetik, 2015: 206). However, since it is unlikely that such features as speech, tone of voice, posture and real energy affecting people in a physical space can be reflected in these virtual spaces, the network of personal relationships and the closeness of thought in virtual communities often can not move to the real world.

Users share and interact because they feel good and valuable to express themselves. Some research shows that inward-looking individuals prefer to communicate and built relationship via the Internet (Kılıç, 2016: 70). For individuals who have difficulty expressing themselves in real life, internet is an important platform in which they can show themselves as they want and feel valuable. Creating an identity within an application and doing its curation is a fundamental principle that leads to an increasingly strong emotional connection with that practice. Making a profile that represents a user's identity provides motivation, satisfaction, and personal value for users (Yetişkin, 2016: 30).

According to the use and satisfaction approach, people consume the media according to their own needs. Accordingly, in order to understand how and to what extent the media is consumed by the audience, it is necessary to look on the needs of the spectator. The sociological and psychological origins of the needs are examined. People are investigated to find out which media messages they use to supply their needs. At the heart of this approach is the belief that audiences have a complex set of requirements that they are trying to get away from the media. The traces examine the satisfaction of people using the media and the use and satisfaction approach that is based on the fact that mass members seek out the most satisfying mass media content in one way or another (Demir, 2013: 110-111). Such researches have shown that satisfactions are the search for information, entertainment, surveillance, digital relationships, identity, status and acquisition (Sütçü ve Algül, 2013: 65). In today's communication world, where radio and television are trying to feed more entertainment than the traditional media, it seems that the new media is more effective in meeting these new satisfactions.

Living in the virtual space where being on-line is associated with being in life, where the being in sight corresponds to the presence; life ise shaped around the performances exhibited by the participants among the other participants. The identity performance, which is called self presentation, is not static or singular according to the identity theoreticians, nor can it be considered separately from the social context at the same time. Performances; Therefore, the 
self-presentations are formed in a conciliatory manner according to the desires of showing performance and the expectations and reactions of others (Özkan, 2014: 250).

It is understandable that a person who performs his / her work all day at the computer uses to satisfy his / her sociological and psychological needs through computer. It is not surprising that in the postmodern era, when white-collar workers, most of whom are computerbased, make use of computers and new media technologies to communicate and relax, as well as to get things done. Most white-collar workers while working at computer also supplies their natural needs, such as socializing and enjoying by creating free time. This also rescues workers from being exposed to the warnings of bosses who see two or three people chatting together. It is not easy for bosses to understand what workers are doing on the computer (whether they work, hang on social media or play games?). Like in "Modern Times" just like Charlie Chaplin, who is kept in strict control by his boss at the factory and gets crazy because of working too much and jammed between the wheels of the machine, in "Postmodern Times" workers are stuck between 0 and 1 of digital technologies. For escape and relaxation, also they can't go far away and they found escape and relaxation areas in their computers. While sitting alone at his desk, to resolve the the feeling of lost and loneliness and to say that "I am here" he/she communicates with the virtual community connected to the computer. Most of this mass which work on computer until late hours are no longer possible to use the old methods of communicating, because of the tiredness or habits of overworking. The majority of these people who are living alone in big cities and apart from their families, continue their new behavior in their private lives brought about by their working conditions. A person who is mailing, talking on the phone and communicating with hundreds of people a day for work can sometimes be distanced from the door neighbor and away from the person working on the same office. The process of socialization and communication which used to provided by talking face to face, is now provided through new media by liking, sharing, and emojis. It seems that those who have difficulty in adapting to this have gradually been left out of this community and forgotten.

However, the internet, which is applied to get rid of loneliness, can turn into addiction over time and, on the contrary, it becomes a source of loneliness and leads to diseases. It is inevitable that new media users, especially new media addicts or those who have to constantly use new media for their business, will face some physical and mental problems. Diseases such as pain, neck hernia, straightening of cervical spine caused by overloading in some points of your body such as fingers, ankles, arms and neck have started to be seen frequently in new media users. Those who are dependent on virtual addiction tend to feel loneliness, depression and nettlesome. There are also findings that relate depression closely with excessive internet use. In one study, it is stated that 30 percent of computer addicts developed internet addiction in order to get away from negative emotions (Tarhan, 2016). In the meantime, the number of people who die while taking a selfie has reached unimaginable figures. Lastly, the two young men who fall down from waterfall because of the slippery algae while trying to take a selfie on the shore in Samsun are like a sign that these deaths will not be the last. Selfie madness, the desire to share in the social media, without living properly the events and without seeing with the eyes and sending to the brain and to show people how constantly they are enjoying and travelling, is increasing day by day.

Specialist Clinical Psychologist Aslı Başabak Bhai, who noted that internet addiction increased in both adults and adolescents, states that it is necessary to limit the time we spent on the internet by realizing how much we are in contact with the internet and determining the most time spent on which applications during the day. Bhai recommends "Call people instead of writing" (Bhais, 2017).

Scientific research has also shown that some people are predisposed to addiction. Individuals with abnormal genes for any reason produce abnormal protein synthesis, which leads to the formation of abnormal enzymes and abnormal receptors. The resulting abnormal enzymes and receptors cause irregularities in the neurotransmitters (carriers between the central nervous system's cells) of the brain's pleasure and reward pathways. As a result, consists a status for loss of control over drug use. The internet is also rewarding because it allows you to escape from your identity, not to have a major cost other than monthly bills, to be 
available 24/7, to be filled with content that constantly innovates and creates interactive communication place. It is also fastmoving with its controllable property that you can enter and leave everywhere you desire without feeling threatened (Tarhan, 2016).

The new media, with both rewarding and fastmoving characteristics, has reached different dimensions with the development of smartphones. Smartphones have become a device in which people can never give up in life, with people having to create their own identities and be willing to be active all the time and with many applications. The feeling of not being able to stay away from the phone and the fear that is caused by the lack of communication when away from the phone is a psychological discomfort that comes from this development. Nomophobia, the lack of mobile phones, emerges as one of the modern fears of the 21st century. In today's conditions, people are able to do all their work easily with one click, actively use social media platforms, and therefore the basic symptom of this disease is the feeling that things will go bad when they are away from the phone and the internet. These diagnoses can be found in many smartphone users whom actually get caught this disease without noticing. In Nomophobia, while away from the smartphone, if he or she is being stressed or panic, unable to perceive the surrounding events and constantly feeling the need to control the mobile device the patient is still in the first stage. If the hormones that give the person a sense of happiness are secreted when the person is informed of the device, this indicates that the addiction phase is increasing. In order to avoid the nomophobia situation or symptoms that are confronted as a cerebral disorder, users need to be aware of how much time they spend on smart mobile devices and to control themselves for conscious use (Polat, 2017: 168). Especially for the young people who sees the internet as only source for information it may be helpful not to take their phones from time to time and to develop alternatives, rather than just storing everything on the mobile phone from directions to their closest friend's phone numbers, from personal information to passwords.

Another psychological disease brought by the new media is "Netlessfobia". Netlessphobia is far more than, "Pathological Internet Usage" and "Intensive Internet Usage" which is included in internet addiction, it is a disease that person can not stay in a place without internet and feel intense anxiety and discomfort about it. The concept of "Netlessphobia", which is used in the meaning of "fear of not being able to use internet", is a concept that has been introduced to explain mental and psychological troubles in people who have exhibited phobic features in certain directions from an analogy and hypothesis. To call a person "Netlessphobic" is not enough just to spend a lot of time on the internet or just to carry a smartphone online. The person has to have great difficulties in the non-internet environment, show physical reactions in the lack of internets, always making alternatives to be on the internet, and always want to update or control a profile. It is possible to list the indications of netlessphobia as follows: using computer-based devices with more than 3 internet connections for personal use and using them together often, using social space preferences for wifi connected places, being online for more than 10 hours a day, have the belief that they will miss and not catch something when the internet is interrupted, keep Internet-connected devices in reachable distance even while sleeping, enjoyment of announcements, message sound, can't stand more than 1 hour without internet, more than 20 social notifications per day, constantly prefer online ones instead of real alternatives (daily tasks, meal order, payment... etc.), being addicted to the internet and the nomophobic (Öztürk, 2015: 633). An individual who is Netlessphobic without his or her own wishes, enters an internet by a computer or mobile phone or any other portable communication device at work, in a school or in a social environment to maintain his / her virtual life involuntarily (Güney, 2017: 210). Besides the psychological effects of computer / internet addiction, there are also physical effects. Overuse of the computer/phone/tablet causes physical disorders or diseases such as Carpal Tunnel Syndrome (a disease that causes numbness, pain, loss of sensation and loss of strength in the hand wrist) cervical disc hernia, hernia of the loins., dryness in the eyes, migraine aches, back pain, malnutrition such as skip meals or obesity, sleep disorders, changes in sleep patterns, and so on (isikun.edu.tr, 2017).

Carpal Tunnel Syndrome, which is common in people who use keyboard and mouse most often limits daily life when it is untreated. It is a disease that causes pain, numbness or paresthesia in the hands and wrists. Carpal Tunnel Syndrome is the result of a constriction of

DOI NO: 10.7456/ctc_2017_02 
the structure called the median nerve, which plays a major role in the movement and feeling of the fingers. The disease seen in every 100 people affects mostly women. The reason for this is that women have a different connective tissue, the hormonal difference and the width of the carpal tunnel are different. In Carpal Tunnel Syndrome, patients are most likely to have pain in their hands and ankles, which can be as severe as waking from sleep at night. Paresthesia and numbness in the fingers are another typical symptom of nerve compression. Nerve entrapment is usually the first 3 , and half of the 4 th finger causes numbness and pain. This problem can be limited to only 3 or 2 fingers in some patients. In the following period, when the pain is exacerbated, the feeling of numbness also increases. As a result, the patient may have a great deal of difficulty in driving a car, combing his hair, talking on the phone, writing articles, holding objects such as cups, plates or bags, or even the paper (hürriyet.com.tr, 2012).

Excessive and improper use of technological devices such as smart phones, tablets and computers is also a trigger in the lower back and neck hernias. Especially in white-collar workers and hours working with computers, the cervical disc hernia has become very common. It is stated that there is a direct correlation between the progress of the technology and the increase in the number of cervical disc hernia. Keeping the neck in the same position and in the wrong position (while watching television, working at the desk, working with the computer) leads to problems in neck. Taking a close look at computer, telephones and tablets will undoubtedly lead to forward tilt and disruption of the spinal system. Neural Surgery Specialist Op. Dr. Şeref Öztürk who say one of the most common problems in everyday life is the neck pain which can be a warning for the cervical disc hernia, states that in this point, attention should be paid to the posture while using smartphones, tablets, computers. Öztürk said that in order not to be a victim of technology one should be careful in this regard, and that one should pay careful attention not to bend his or her head to shoulder level when one is texting on the phone or browsing something on the tablet (aydinlik.com.tr, 2017).

It is difficult to predict the dimensions that digitalization will have and the problems will bring in the future. In a world where the number of digital immigrants is decreasing day by day and the dominance of digital natives is rapidly increasing, with the spread of digitalization in every field, there may be some changes in human body and soul in the future. Our fingers that we constantly use for digital technology will may get longer and stronger over time, perhaps fingertips will get thinner to adapt to the touchscreen. Or maybe our neck will be toward the front, not straight-up, and body shape will change. In the future against the cervical disc hernia we may even wear iron hoops like the women of the Padaung tribe in Thailand and make it fashionable and solve the problem. Or perhaps we will never need them in the future because of hopefully digitalization will no longer be touch-operated thanks to smarter "Siri" or AR (Augmented Reality) and find alternative devices than mouse to reduce the pressure on our fingers and shoulders. In recent years, our contact and dependency with technology has been increasing day by day, as a Swedish company has started a new application by putting a chip under the skin of its employees instead of digital ID cards. As in the 1993 film Demolition Man, played by Sylvester Stallone and Sandra Bullock, it will be clear in the future that whether a chip will be implemented to everyone, everything is followed, even physical contact is forbidden, sexuality is allowed only through the virtual world, all the tools we use at work and at home are digitized, a society, in which everything is asked to the computers, is created or after a point, like people who are bored from urban life return to the nature, people will also get bored of virtual life and stick to the real life.

\section{Result}

"Immobile socialization" distinguishes individuals who have lived in the age of technology from past generations. The prototype of the new generation has the opportunity to define itself in the virtual space by permanently rebuilding its identity or creating alternative identities from his or her desk thanks to internet technologies (Sağır, 2016: 222). In those people who are happy in virtual worlds and who achieve satisfaction by getting what they want, the internet can reach the extent to addiction over time. 
Addiction to the world of imagination created by the media has been existed for a long time. However, when we compare new media and old media addiction, it seems that the new media is more and more connected to and attracted to oneself. It is possible for a person watching a series on the internet to watch an entire season in one or two days at all times, while a television addict is required to return to reality at least during the commercial and wait for one week for the next episode. From this point of view, it is possible to say that duration and the dosage of the trance in old media is limited and lighter while dosage of the trance and withdraw from the reality is higher in new media. The phenomenon of "alienation" that emerged with modernization has moved to a different point with the digital revolution that has become evident with postmodernism. The "virtual reality" brought about by the digital revolution has severed the connection with the "real" environment and increased its dependence on the virtual environment. In this context, to reduce individual and social distortions, it is necessary to carry out various studies in order to educate qualified and informed users who are literate in the transformations realized by digitalization, in order not to become users of digital media as unconscious and "passive interactive" new media users (Güney, 2014: 5, 165).

Children should not be debarred from the Internet benefits due to its potential hazards and children should be equipped with the knowledge and skills which are necessary to explore virtual reality in a safe and responsible manner and the concept of rights and responsibilities should be extended from the real world to the internet world. Especially, for technologyequipped students of the future, new media literacy is very important. Just as information literacy is often related with research skills, media literacy is related with critical analysis of various types of media content and new media literacy should be related with the ability to use computers, the Internet and social media, and critical analysis of these environments. Utilize new media consciously is very important for the protection of both body and mental health. It is highly possible for those who do not use the new media consciously to have psychological problems such as internet addiction, nomophobia, netlessphobia, or have physical problems like neck ache, spinal disc herniation and carpal tunnel syndrome. Experts also emphasize the necessity of increasing the physical activities against the aches which are the results of physical stagnation caused by technology.

\section{References}

[1] Akca, E. B (2014). Demokratik Katılım Bağlamında Yeni Medya ve Dijital Yurttaşlık. Yeni Medya Yeni Pratikler Yeni Olanaklar içinde. 1. Basım. Kocaeli: Umuttepe Yayınları.

[2] Altunbaş, F (2014). Sosyal Medyaya Genel Bir Bakış. Müge Demir (Ed.), Yeni Medya Üzerine Vol.2. içinde (45-92). 1. Basım. İstanbul: Literatürk Academia Yayınları.

[3] Arar, Y. B (2014). Bir Kuşak/Zihniyet Çatışması Bağlamında Geleneksel Medya-Yeni Medya Gerilimi ve Gazetecilik Eğitimi. Müge Demir (Ed.), Yeni Medya Üzerine Vol.2. içinde (121-146). 1. Basım. İstanbul: Literatürk Academia Yayınları.

[4] Aydınlık.com.tr (2017). Yanlış Kullanım Fıtık Ediyor. https://www.aydinlik.com.tr/saglik/2017-haziran/yanlis-kullanim-fitik-ediyor

[5] Binark, M. ve Bayraktutan G (2013). Yeni Medya ve Etik. 1. Basım. İstanbul: Kalkedon Yayınları.

[6] Binark, M (2014). Yeni Medya Çalışmalarına Araştırma Yöntem ve Teknikleri. 1. Basım. İstanbul: Ayrıntı Yayınları.

[7] Bhais, Z. B (2017). İnternet Bağımlıı̆ının Tedavisi ve Ailenin Tedavideki Yeri. 4. Uluslararası İletişim Günleri. Üsküdar Üniversitesi İletişim Fakültesi. 27-28 Nisan 2017. http://www.uskudar.edu.tr/tr/icerik/2233/dijital-bagimlilik-2-gun-suren-4-uluslararasiiletisim-gunlerinde-tartisildi-

[8] Çakır, M (2014). Yeni Medyaya Eleştirel Yaklaşımlar. 1. Basım. İstanbul: Doğu Kitabevi.

[9] Çakır, S. Y (2014). Marka Toplulukları: Markaların Sanal Ortamdaki Etkileşim Alanları. Emel Baştürk Akca, (Ed.). Yeni Medya Yeni Pratikler Yeni Olanaklar içinde. 1. Basım. Kocaeli: Umuttepe Yayınları.

[10] Dedeoğlu, G (2016). Teknoloji, İletişim, Yeni Medya ve Etik. 1. Basım. İstanbul: Sentez Yayıncılık.

[11] Demir, M (2013). Yeni Medya Üzerine. 1. Basım. İstanbul: Literatürk Academia Yayınları. 
[12] Erdoğan, İ (2014). Yeni Medya Gazeteciliğinde Etik Bir Paradigma Belirlemenin Kapsamı ve Sınırları. Emel Baştürk Akca, (Ed.), Yeni Medya Yeni Pratikler Yeni Olanaklar içinde (s. 79-102). 1. Basım. Kocaeli: Umuttepe Yayınları.

[13] Freud, S (2007). Uygarlık, Din ve Toplum. 6. Basım (Çev. Selçuk Budak). İstanbul: Öteki Yayınevi

[14] Hürriyet.com.tr. (2012). Bu hastalık mouse tutan elleri seviyor. Beyin ve Sinir Cerrahisi Uzmanı Yrd. Doç. Dr. İbrahim Sun. http://www.hurriyet.com.tr/bu-hastalik-mouse-tutanelleri-seviyor-19906924 [04.08.2017]

[15] Gün, F. S (2013). Tüketici Özgürlüğü@ sosyalmedyareklamlar.com. And Algül ve Neda Üçer ( Ed.), Yeni Medya'da Demokrasi içinde (s. 83-112). İstanbul: Literatürk Yayınları.

[16] Güney, B (2017). Dijital Bağımlılığın Dijital Kültüre Dönüşmesi: Netlessfobi. İstanbul Aydın Üniversitesi. e-Journal of New Media / Yeni Medya Elektronik Dergi - eJNM May 2017 Volume 1 Issue 2 Submit Date: 18.03.2017, Acceptance Date: 18.04.2017, DOI NO: 10.17932/IAU.EJNM.25480200.2017.1/2.207-213

[17] Güney, E (2014). Dijital Görsel Kültür ve Yeni Medya Ekseninde Sanatın Değişen Rolü. Ondokuzmayıs Üniversitesi Eğitim Bilimleri Enstitüsü Güzel Sanatlar Eğitimi Anabilim Dalı. Doktora Tezi. Tez Danışmanı: Doç. Dr. Ali Seylan. Samsun, 2014.

[18] Gürer, M (2015). TV İstasyonlarının Web ve Sosyal Medya Kullanımı. Sedat Özel (Ed.)Yeni Medya Çağında Televizyon içinde (s. 36-64). 1. Basım. İstanbul: Derin Yayınları.

[19] Işık Üniversitesi (2016). Bilgisayar / İnternet Bağımlıı̆ğ. Psikolojik Danışmanlık Merkezi. http://www.isikun.edu.tr/hakkinda/yonetim/rektorluk/psikolojik-danismanlik-merkezi/yeniogrenciler/bilgisayar/internet-bagimliligi

[20] Kahraman, M (2014). Sosyal Medya 101 2.0. 3. Basım. İstanbul: Mediacat kitapları.

[21] Karaduman, H (2014). Dijital Dünya'da Dijital Vatandaşlık Eğitimi Nasıl Olmalı? Emel Baştürk Akca, (Ed.), Yeni Medya Yeni Pratikler Yeni Olanaklar içinde (s. 103-126). 1. Basım. Kocaeli: Umuttepe Yayınları.

[22] Karagöz, U (2016). Dijital Dönüşüm ve Türkiye. İdarecinin Sesi, 171. sayı, Mayıs Haziran 2016.

http://www.igb.gov.tr/Kutuphane/ugurkaragoz_Dijital\%20D\%C3\%B6n\%C3\%BC\%C5\%9 F\%C3\%BCm\%20ve\%20T\%C3\%BCrkiye.pdf

[23] Kılıç, N. S (2016). Sanal Alem Üzerine Schutzcu Bir Çözümleme. A. Çağlar Deniz ve Banu Hülür (Ed.), Yeni Medya ve Toplum içinde (s. 57-78). 1. Basım. İstanbul: Literatürk Academia Yayınları.

[24] Kıpçak, N. S (2016). Yeni Karnaval Olarak Yeni Medya: Karnavalesk Nitelikleri Ile Twitter. Marmara Üniversitesi Sosyal Bilimler Enstitüsü Radyo Tv Sinema Anabilim Dalı İletişim Bilimleri Bilim Dalı Doktora Tezi. Danışman: Prof. Dr. Mukadder Çakır İstanbul.

[25] Kürkçü, D. D (2016). Yeni Medya ve Gençlik. Birinci Baskı. İstanbul: Kriter Yayınevi.

[26] Lievrouw, L. A (2016). Alternatif ve Aktivist Yeni Medya. I.S. Temizalp (çev.). İstanbul: Epsilon Yayınevi.

[27] McMillan, S. J. ve J. S. Hwang (2016). Algılanan Etkileşimlilik Ölçümleri - Etkileşimlilik Algılamalarını Biçimlendirmede İletişimin Yönü, Kullanıcı Kontrolü ve Zaman Keşfi. Himmet Hülür ve Cem Yaşın (Ed.), Yeni Medya Kullanıcının Yükselişi içinde (s. 373395). H. Hülür ve B. Ayaz (çev.). Ankara: Ütopya Yayınevi.

[28] Moore, G (2017). Dengesizlik, Bozukluk ve Dopamin Etkisi: Teknoloji Her Zaman Bağımlıı Yapmıştır, Dijital Medya Neden Farklı Olsun? 4. Uluslararası İletişim Günleri. Üsküdar Üniversitesi İletişim Fakültesi. 27-28 Nisan 2017.

http://www.uskudar.edu.tr/tr/icerik/2233/dijital-bagimlilik-2-gun-suren-4-uluslararasiiletisim-gunlerinde-tartisildi-

[29] Noyan, C. O (2017). Neden Bağımlı Oluyoruz? 4. Uluslararası Illetişim Günleri. Üsküdar Üniversitesi İletişim Fakültesi. 27-28 Nisan 2017.

http://www.uskudar.edu.tr/tr/icerik/2233/dijital-bagimlilik-2-gun-suren-4-uluslararasiiletisim-gunlerinde-tartisildi-

[30] Özkan, G. Ş (2014). Ağ Tabanlı Sahnede Benliğin Sunumu: İdealize Edilmiş Duygular. İdil Sayımer (Ed.), Yeni Medya Araştırmaları içinde (s. 244-282). 1. Basım. İstanbul: Literatürk academia Yayınları. 
[31] Öztürk, M. S (2017). Dağ Medya ve Türkiye'de Veri Gazeteciliği. Erkan Saka, Vehbi Görgülü ve Anıl Sayan (Ed.). Yeni Medya Çalışmaları IV Dijitalleşen Gazetecilik İçin Yeni İş Modelleri içinde (s. 241-260). 1. Basım. İstanbul: Taşmektep Yayınları.

[32] Öztürk, U. C (2015). Bağlantıda Kalmak ya da Kalmamak İşte Tüm Korku Bu: İternetsiz Kalma Korkusu ve Örgütsel Yansımaları. Uluslararası Sosyal Araştırmalar Dergisi. Cilt: 8 Sayı: 37. Nisan 2015. www.sosyalarastirmalar.com ISSN: 1307-9581

[33] Pavlik, J. V (2013). Yeni Medya ve Gazetecilik.1. Basım. M. Demir, B. Kalsın (çev.). Ankara: Phoenix Yayınevi.

[34] Polat, R (2017). Dijital Hastalık Olarak Nomofobi. İstanbul Aydın Üniversitesi. e-Journal of New Media / Yeni Medya Elektronik Dergi - eJNM May 2017 Volume 1 Issue 2. Submit Date: 20.03.2017, Acceptance Date: 21.04.2017, DOI NO: 10.17932/IAU.EJNM. 25480200.2017.1/2.164-172

[35] Sağır, A (2016). Facebook Gruplarında Üretilen Taraftar Kimlikleri. A. Çağlar Deniz ve Banu Hülür (Ed.), Yeni Medya ve Toplum içinde (s. 215-258). 1. Basım. İstanbul: Literatürk Academia Yayınları.

[36] Salı, J. B (2012). Yeni Medya Okuryazarlığı. Deniz Yengin (Ed.), Yeni medya ve... içinde (s. 291-309). 1. Basım. İstanbul: Anahtar Kitaplar Yayınevi.

[37] Sütçü, C. S (2012). Sosyal Medyaya Girmeden Önce Bilinmesi Gerekenler. Deniz Yengin (Ed.), Yeni medya ve... içinde (s. 74-89). 1. Basım. İstanbul: Anahtar Kitaplar Yayınevi.

[38] Sütçü, C. S. ve A. Algül (2013). Teknolojinin Toplum Üzerindeki Etkisi Açısından İnternetin Kısıtlı Sosyal Çevresi Üzerine Bir Araştırma. And Algül ve Neda Üçer (Ed.), Yeni Medya'da Demokrasi içinde (s. 55-81). İstanbul: Literatürk Yayınları.

[39] Tarhan N (2016). İnternet Bağımlılı̆ı̆ Hakkında Her Şey... Men's Health/Eylül 2016. http://www.nevzattarhan.com/internet-bagimliligi-hakkinda-her-sey-.html

[40] Tarhan, N (2017). Dijital Bağımlılık. 4. Uluslararası İletişim Günleri. Üsküdar Üniversitesi İletişim Fakültesi. 27-28 Nisan 2017. http://www.uskudar.edu.tr/tr/icerik/2233/dijitalbagimlilik-2-gun-suren-4-uluslararasi-iletisim-gunlerinde-tartisildi-

[41] Tetik, C (2015). Sosyal Medya Alternatif Bir Kamusal Alan Olabilir mi? Mehmet Gökhan Genel (Ed.), Yeni Medya Araştırmaları içinde (s. 195-217). 1. Basım. İstanbul: Ekin Yayınevi.

[42] Tiryaki, S (2015). Sosyal Medya ve Facebook Bağımlıı̆ı. 1. Basım. İstanbul: Literatürk Yayınları.

[43] Tunçel, A (2014). Gençlerin Sosyal Medya Kullanımı ve Demokratik Siyaset. Emel Baştürk Akca, (Ed.), Yeni Medya Yeni Pratikler Yeni Olanaklar içinde (s. 59-78). 1. Basım. Kocaeli: Umuttepe Yayınları.

[44] TÜIK, (2016). Hanehalkı Bilişim Teknolojileri Kullanım Araştırması, 2016. Türkiye İstatistik Kurumu Başkanlığı. http://www.tuik.gov.tr/PreHaberBultenleri.do?id=21779

[45] TÜiK, (2017). Hanehalkı Bilişim Teknolojileri Kullanım Araştırması, 2017. Türkiye İstatistik Kurumu Başkanlığı. http://www.tuik.gov.tr/PreHaberBultenleri.do?id=24862

[46] Yalçın, G (2017). Gazetecilikte Dijital Değişim: Online Gazetecilik hürriyet.com.tr örneği. Erkan Saka, Vehbi Görgülü ve Anıl Sayan (Ed.). Yeni Medya Çalışmaları IV Dijitalleşen Gazetecilik İçin Yeni İş Modelleri içinde (s. 175-191). 1. Basım. İstanbul: Taşmektep Yayınları.

[47] Yengin, D (2012). Yeni medya ve... 1. Basım. İstanbul: Anahtar Kitaplar Yayınevi.

[48] Yengin, D (2014). Yeni Medya ve Dokunmatik Toplum. 2. Basım. İstanbul: Derin Yayınları.

[49] Yengin, D (2015). Sosyal Medya Araştırmaları. 1. Basım. İstanbul: Paloma Yayınevi.

[50] Yetişkin, E (2016). Sosyal Medya ve Sıradanlaşan Gözetim. A. Çağlar Deniz ve Banu Hülür (Ed.), Yeni Medya ve Toplum içinde (s. 21-55). 1. Basım. İstanbul: Literatürk Academia Yayınları.

[51] Yörükan, T (2017). Alfred Adler'in Benimsediği Görüşler. Felsefe. https://www.aymavisi.org/felsefe/Alfred\%20Adler'in\%20Benimsedigi\%20Felsefi\%20Gor usler.html 